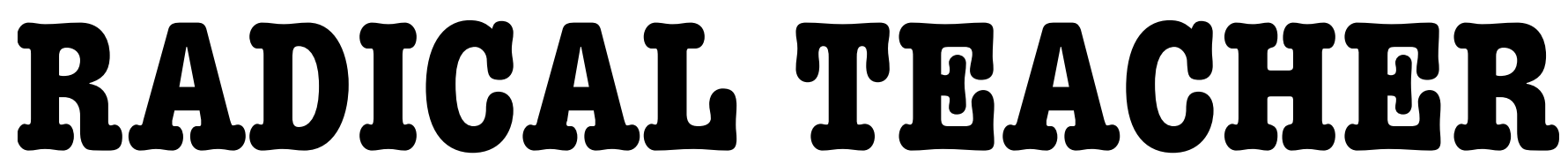

A SOCIALIST, FEMINIST, AND ANTI-RACIST JOURNAL ON THE THEORY AND PRACTICE OF TEACHING

\title{
Ask More Questions?
}

\author{
By Allison L. Ricket
}

\section{L} ast year I had a real spitfire in my eleventhgrade English class. He was the most ready to challenge majority views, push his classmates to support their ideas with credible facts, or listen seriously about the need to tackle clichés in his writing.

Then, in January, I made a critical mistake that cost me the vitality of this student.

The class writes research papers in January, and I wanted to invite the students to research a social justice issue they knew nearly nothing about. We watched TED talks and read articles on the failings of abstinence-only education, plastic in the ocean's gyres, the Bechdel test, and the crushing standardization of public schools. Their assignment was to research a problem and then argue for a solution or a set of solutions to fix the problem.

\section{I wanted my student to know what was happening to his community. In an informal poll at the beginning of the year, I found out that only two students in all my classes knew what Fracking was -- which is a desperate situation considering people in the county, their parents, are leasing their land left and right to the gas companies.}

What I didn't want was another pro-life diatribe, antimarriage equality tirade, or pro-assault weapon essay that, although properly reflecting the majority beliefs of the community, would not allow enough serious inquiry into the unknown.

To facilitate the choosing of a topic, I assigned the students the task of randomly selecting three TED talks or articles and using those texts to generate questions for further research. As each student brought their three texts to me and we discussed their questions and potential for research papers, I made suggestions, offering what I knew on the topic with the intention that the students would have somewhere to start.

\section{I made a critical mistake that cost me the vitality of this student.}

My conversation with the spitfire went like this:

Student rushes up to me in the hall, breathless with indignation. "Ms. Ricket, I just watched the most disgusting thing I've ever seen in my life." No pause for me to react. "In Canada, there is a lake the size of Manhattan filled with waste from the tar sands. One man can't even feed his family now because the water is so polluted. It's so crazy disgusting. You have to watch it."

At once I was filled with pride, disgust, and excitement because I thought we were on the verge of a "teachable moment." This is where I made that fatal mistake. I stepped out of the process of inquiry and into the sage-onthe-stage role.

"You know," I said, with a conspiratorial grin and an air of insider authority, "something just like the tar sands is happening right here in our town. It's called Fracking. Natural gas companies contaminate huge amounts of water and then dump it back into the ground where it's contaminating people's drinking water, hurting agriculture, and even causing earthquakes. Some people can now literally light water coming out of their faucets on fire because of Fracking."

Everything I said was $100 \%$ true. Fracking - the process of extracting natural gas from the shale in the 
mountains - is devastating many areas of Appalachia. Companies drill here and inject their dirty, radioactive water in the poorest counties - they would never conceive of putting an injection well in their communities - yet they tell us all it's "safe."

I wanted my student to know what was happening to his community. In an informal poll at the beginning of the year, I found out that only two students in all my classes knew what Fracking was -- which is a desperate situation considering people in the county, their parents, are leasing their land left and right to the gas companies.

I wanted to show him the injustice of the entire process, for him to be just as inflamed about Fracking as he was about the tar sands waste. But my intentions -however noble -- were lost.

\section{What I didn't want was another pro-life diatribe, anti-marriage equality tirade, or pro-assault weapon essay that, although properly reflecting the majority beliefs of the community, would not allow enough serious inquiry into the unknown.}

He did do his research paper on the detrimental effects of Fracking. Not because he had a burning desire to know and learn, but because he wanted to do what I suggested. He completed the additional assignment for the paper of interviewing a primary source. In fact, he did better than I assigned. He got himself invited to a Fracking well in a neighboring county.
He came back from this encounter pumped up by the heavy machinery and the machismo of the men operating it. He burst into my room announcing in his enthusiastic way, "My paper is all lies." Fracking, he concluded, is wonderful, fascinating, and safe. He did ask questions to the gas company representative present on site, and they fed him many of the public answers I've seen in the papers. He has since decided to pursue petroleum engineering in college.

A veteran teacher told me, after I'd relayed this story as a dismal failure of my teaching ability, that our job as teachers is to help students learn to think - not tell them what to think.

What I've been able to take away from this situation is that I would have furthered the cause of Environmental Justice much more had I simply asked more questions. I could have followed my student's lead, asked questions such as, "What do you feel is most unjust about the tar sands situation?" "What could be done about this injustice?" or "Are there more situations in which people are losing homes and resources to the tar sands mining?"

As a teacher interested in social action, I wonder if critical thinking -- teaching "how" to think - is more important than presenting the students with a situation and declaring it unjust. I wonder how I leave room for the students to refuse to see injustice even after a full, successful inquiry process. Perhaps I was right to alert him to the issue of Fracking in his hometown, to assign it the status of "unjust" outright. Perhaps, as teachers of social justice, we have to be willing to stand quietly in truth sometimes, to let the wandering wander and let them figure it out themselves - but I also wonder if as a society, as a planet - we can afford the time that takes. (c)) BY-NC-ND

ULLS D-Serle
This work is licensed under a Creative Commons Attribution-Noncommercial-No Derivative Works 3.0 United States License.

This journal is published by the University Library System of the University of Pittsburgh as part of its D-Scribe Digital Publishing Program, and is cosponsored by the University of Pittsburgh Press. 